\title{
Uma experiência de filosofar: Sócrates
}

\author{
Walter Omar Kohan \\ UERJ-CNPq
}

Antes que mais nada, agradeço intensa e sinceramente o convite de Paula Ramos para este evento, que muito me alegra e honra. Como o tema da mesa é "A experiência do filosofar", talvez seja interessante - para pensar nossas experiências presentes - re-visitar uma das experiências primeiras, uma dentre as mais nomeadas e espelhadas do filosofar, como é a experiência de Sócrates.

Sócrates é para nós, um enigma, deliberado e obstinado. Há um problema hermenêutico indissimulável. Ele próprio preferiu não escrever suas experiências. Nosso acesso a elas está mediado duplamente, por uma escritura, que é a escritura de outro, um discípulo, amigo, amante. A testemunha é ambivalente. Passa de figura central e dominante a voz jovem $e$ tênue. Num mesmo texto - ou em textos muito próximos - , ele diz e se desdiz. Consideremos alguns exemplos. Ele afirma, a um tempo só, na Apologia, que é o mais sábio de todos os homens e que seu saber pouco vale (Apologia 20d ss.). Diz também, ao mesmo tempo, que é o único ateniense a praticar a verdadeira política (Górgias 521d) e que fez bem em não praticar a política porque senão teria morrido muito antes (Apologia 31c-e).

Afirma, também na Apologia (33a ss.), com poucas linhas de diferença, que não foi mestre de ninguém e que seus discípulos continuarão fazendo o que ele fazia. Pode-se perceber que não são questões de detalhe; ao contrário, elas atingem o coração do que se entende por filosofia, por política e por educação. O Sócrates de Platão, o mais transitado na história das idéias, abre caminhos opostos em cada um desses campos.

É claro que essas contradições não são intransponíveis e precisam ser pensadas e discutidas, como procuraremos fazer aqui. Mas importa também perceber que elas dizem respeito a um modo inaugural de delimitar o próprio espaço da filosofia, de se referir a uma experiência de filosofia. Visto de um exterior nada simples, a uma distancia tensa e complexa, o filósofo convida a uma experiência: chama os outros para pensar - num jogo ambivalente e por momentos contraditório de pensamento - em coisas tais como a educação e a política. A filosofia se propõe como uma experiência de encontrar sentidos múltiplos, opostos, nas significações únicas. Abre assim todo um espaço para outra política e para outra educação que as instituídas.

Essa experiência primeira da filosofia também instaura toda uma série de diferenciações: ela distingue entre o aparente e o escondido, entre o que parece ser $e$ o que é, entre o que se pensa e o que se deveria pensar, entre o que se valoriza $e$ o que se deveria valorizar, entre o que se faz e o que se deveria fazer, entre o que se é e o que verdadeiramente se deveria ser. Também dessa forma instaura toda uma política e uma educação do pensamento de ressonâncias fortes, violentas, temíveis. 
Sócrates é, pelo menos para nós, quem claramente inaugura esse espaço, o consagra, e o faz contrapondo a filosofia à política, pelo menos àquela que fazem os políticos. Na verdade, situa a filosofia no meio da política e da educação, num espaço que era reservado à política, que a política guardava, límpido, direto, incontaminado. Com a presença da filosofia nesse espaço, a política e a educação se abrem a novas formas. Assim, o embate entre Sócrates e seus oponentes se dá entre duas formas de entender e praticar a política $e$ também entre duas formas de entender e praticar a educação. É a filosofia, pelo menos a filosofia de Sócrates, que tem marcado essas duas cisões. É ela que tem provocado essas dualidades.

Não podia ser menos se ela própria é, como antecipamos, cheia de tensões, dualidades, contradições. Neste texto analisaremos dois exemplos testemunhados dessa experiência que oferecem elementos contrastantes, opostos. Leremos dois diálogos de juventude de Platão e veremos o que eles nos dizem sobre o modo socrático de experienciar a filosofia.

\section{Um exercício sagrado}

Vamos analisar o exercício de um dos primeiros diálogos de Platão, o Eutífron. Lembremos o seu início. Sócrates, na busca da acusação escrita contra si próprio, encontra, na porta dos Tribunais, Eutífron, que iria iniciar um processo contra seu próprio pai por este ter assassinado um vizinho. $\mathrm{O}$ motivo não é menor: alguém que se diz especialista em questões sagradas pode - ao acusar seu próprio pai perante os tribunais - estar de fato iniciando uma ação contrária, nefanda (3e-5a). Sócrates, então, aproveita a oportunidade para se colocar como discípulo de Eutífron e pede para lhe explicar como são o sagrado e o nefando, dos quais Eutífron se declara conhecedor (5c) ou, em outras palavras, o que é o sagrado e o que é o nefando $(5 \mathrm{~d})$.

Inevitavelmente, Eutífron falha em todos seus intentos de responder as perguntas de Sócrates. A primeira tentativa sugere que o sagrado é o que ele está fazendo nesse momento, qual seja, instaurar um processo contra quem é injusto, sem importar quem é que faz a injustiça e o tipo de injustiça que ele faz; ao contrário, não instaurar tal processo nessas circunstâncias seria um ato nefando ( $5 \mathrm{~d}-e$ ). Sócrates responde que, de fato, Eutífron não respondeu sua pergunta inteiramente. Ele apenas deu um exemplo ou caso de algo sagrado e de algo nefando, mas não contemplou muitas outras coisas que também são tais (6d). Sócrates especifica ainda mais seu pedido: ele quer a idéia mesma (eîdos, idéia, 6d-e), o paradigma, pelo qual as coisas sagradas são sagradas e as nefandas são nefandas.

Na sua segunda tentativa, Eutífron também não satisfaz Sócrates. Ele afirma que "o amado pelos deuses é sagrado e o que não é amado pelos deuses é nefando" (6e7a). A contra-argumentação de Sócrates (7a-8b) pode resumir-se da seguinte forma: os desacordos se dão, entre deuses e seres humanos, precisamente pelos sentimentos que eles têm sobre coisas como o justo e o injusto, o bom e o ruim, o sagrado e o nefando. Isto significa que alguns deuses amam algumas coisas $e$ outros deuses odeiam essas mesmas coisas. Assim, as mesmas coisas são amadas e odiadas pelos deuses e, desse modo, a definição proposta por Eutífron leva à 
contradição, na medida em que algumas coisas seriam amadas e odiadas pelos deuses e, portanto, sagradas e nefandas ao mesmo tempo.

$\mathrm{O}$ argumento é falacioso. Sócrates parte de uma premissa que ele mesmo não considera verdadeira (que existam diferenças substantivas nos deuses quanto ao que é amado ou odiado por eles, cf. a este respeito o livro II de $A$ República ou o próprio Eutífron 9c-d). O critério dado por Eutífron pode não ser aquele que Sócrates está procurando na medida em que não oferece o paradigma ou idéia "pela qual todas as coisas sagradas são sagradas (e as nefandas, nefandas)", mas ele não é contraditório: se alguns deuses amassem certas coisas e outros deuses odiassem essas mesmas coisas isto apenas indicaria que para tais deuses não são sagradas e nefandas as mesmas coisas. Se isto é problemático para Sócrates, o problema está na concepção dos deuses pressuposta ou na sua pretensão de uma resposta única e universal para sua pergunta, mas não na definição oferecida por Eutífron.

Mais ainda, a definição de Eutífron (que não muda substancialmente ao longo do diálogo) não apenas não é contraditória; ela funcionaria se Sócrates partisse de um pressuposto seu, socrático ( $A$ República II), a saber, de que os deuses - pelos menos os verdadeiros deuses ou os deuses de uma verdadeira pólis $3 / 4$ só podem amar e odiar as mesmas coisas. Eutífron tenta mostrar que, pelo menos no seu exemplo, este seria o caso: todos os deuses aceitariam que quem matou injustamente ou fez alguma outra injustiça deve prestar contas perante a justiça (Eutífron 8b).

Porém, a continuação da conversa mostra um Sócrates implacável. Volta a partir de uma premissa ("nenhum dos homens ou dos deuses diria que não deveria prestar contas na justiça quem compete injustiça") que é falsa à luz de suas próprias conversações em outros diálogos (por exemplo, no livro II de A República (357a ss.) dedica uma longa seção junto a 'Adimanto' e 'Glauco' a mostrar que a justiça é preferível à injustiça em função dos que argumentam o contrário). Conclui, assim, que é precisamente em determinar se uma coisa é justa ou injusta em que homens e deuses discordam (8c-e). Eutífron dá sinais de cansaço e, ante a ironia socrática de que certamente explicará aos juízes o que a ele, Sócrates, lhe dá mais trabalho de aprender, responde com mais ironia: "se me ouvirem, lhes explicarei" (9b). Eutífron toca num ponto chave: em muitas passagens dos diálogos, Sócrates parece não ouvir seus interlocutores.

De fato, Sócrates só quer ouvir uma coisa e se não ouve o que quer ouvir não dá descanso ao outro. Sócrates não ouve a resposta de Eutífron. Não é verdade que Eutífron não responde a pergunta de Sócrates. Eutífron não responde a pergunta de Sócrates como Sócrates gostaria que respondesse. Sócrates quer o "quê" e Eutífron dá o "quem". Sócrates pergunta pelo sagrado e Eutífron responde mostrando alguém que faz o sagrado. Por que não? Qual o problema? Acaso cada "que" não esconde um "quem"? Acaso a pretensão socrática de uma natureza, uma idéia, um ser do sagrado não esconde uma afeição como a que oferece Eutífron? Por que uma característica abstraída e universalizada é melhor resposta para entender o "que" de alguma coisa que o sujeito de sua produção? Sócrates bem 
poderia discutir o que de fato não parece querer discutir: o que é que faz que uma coisa "x" seja "x"? É um paradigma ou uma idéia, como ele pressupõe, ou poderia ser algo mais da ordem do aqui e agora, dos afetos e efeitos, da história e da geografia, tanto quanto da metafísica ou da ontologia?

É claro que Sócrates não considera estas perguntas. Impugna as respostas de Eutífron como se suas perguntas só pudessem ser respondidas como ele espera que sejam respondidas. Importa notar a violência deste modo de proceder socrático que é também o modo de proceder com que a filosofia obtém sua certidão de nascimento: a despersonalização do pensamento, sua abstração que o arranca de suas condições de produção, sua universalização que o desconecta de seu universo de sentido, sua intransigência que o isola de outras formas de pensamento. Desta forma, a negação do "quem" não é senão a máscara para a imposição de um "quem" escondido na sua ausência, na sua impostação universal.

Costumamos ler que a filosofia é dialógica, que ela é uma troca entre dois interlocutores que estão dispostos, a partir do encontro com o outro, a repensar seus pressupostos e concepções. Também muitos dizem que os diálogos de Platão são o melhor exemplo de tal filosofia: viva, ativa, em movimento. E Sócrates seria o campeão do diálogo. Pelo menos no caso do Eutífron $3 / 4$ e nos atrevemos a dizer que não só neste caso - toda esta imagem idealizada, benévola e idolatrada da filosofia que nasce com Sócrates é falsa.

Se lermos, com cuidado, diálogos como o Eutífron, vemos uma atividade do pensamento que não sai do lugar e que insiste em pretender que os outros saiam do seu lugar; uma atividade do pensamento que desqualifica as respostas dos outros que não vão ao encontro de suas próprias respostas; uma experiência que é insensível às diversas tentativas de pensar as mesmas perguntas de outro modo, desde outros pressupostos, com outra lógica; ou, mais do que isso, teremos que dizer que a filosofia de Sócrates nasce não aceitando outras perguntas - e um modo específico de entendê-las — do que as que ela consagra para o pensamento?

Os conceitos têm uma história, suas circunstâncias, seus criadores, seus desdobramentos. O próprio conceito tem conceitos de si próprio, conceitos do que é um conceito, um ponto inicial de criação por parte de um filósofo, um percurso que passa por outras criações até sua extinção ou sua sempiterna re-criação filosófica. Com Sócrates nascem muitos conceitos. E nisto há boa parte de sua fortaleza e vitalidade. Mas também há muito de sua violência e mortandade. Isto vale pelo menos para dois conceitos que com Sócrates nascem: a filosofia e o próprio conceito. Eles só podem ser pensados de uma maneira, uma maneira que fustiga, incansavelmente, as outras formas que não se rendem a ela, que não chegam até onde ela quer chegar. Eutífron que o diga.

Deleuze diria que o que caracteriza a filosofia é a criação de conceitos. Por isso Sócrates é filósofo, porque cria inúmeros conceitos, até o conceito do próprio conceito. Diz também Deleuze que os conceitos são inseparáveis dos afetos efeitos potentes que eles têm sobre nossas vidas — , e dos preceitos — novas maneiras de perceber que eles nos inspiram (Deleuze, 2003, p. 218). Também por 
isso Sócrates é um filósofo, pelos inúmeros e poderosos efeitos na maneira de viver as vidas dos seus interlocutores e nas novas maneiras de perceber que eles lhes inspiram. Qual o efeito do Eutífron?

Cada um com seu jogo. O jogo de Eutífron está nos assuntos divinos. E segundo Sócrates, ele não consegue se dar bem nesse jogo. Não mostra saber o que Sócrates quer saber. O jogo de Sócrates está nos assuntos filosóficos. Ele próprio se dá bem nele? Não sabemos. Em todo caso, o que mostra saber é como fazer com que o outro fracasse em mostrar o seu saber, o outro saber, o saber do outro: e ele também mostra saber, segundo veremos a seguir, como fazer para que ele e o outro, depois de muitas voltas, acabem no mesmo lugar de partida. $\mathrm{O}$ mesmo lugar?! É isso se dar bem no jogo da filosofia?

Vamos ver. Na continuação do diálogo, Sócrates insiste. Não é o "ser amado pelos deuses" o critério que determina o "ser sagrado" mas, ao contrário, algo é amado pelos deuses por ser sagrado (9c-10e). Assim, Eutífron estaria confundindo um afeto do "ser sagrado" ("ser amado pelos deuses") e do "ser nefando" ("ser odiado pelos deuses") com o que é "ser sagrado" e "ser nefando". Eutífron já não sabe como dizer a Sócrates o que pensa. Tudo dá voltas ao seu redor. Nada fica quieto (11a-b).

Então, Sócrates se diz descendente de Dédalo (11c). Dédalo é um ateniense da família real, o protótipo do artista universal, arquiteto, escultor e inventor de recursos mecânicos (Grimal, 1989, p. 129). Desterrado depois de matar a seu sobrinho Talo por ciúmes, foi o arquiteto do rei Minos em Creta e construiu o Labirinto onde o rei encerrou o Minotauro. Fez com que Ariadne salvasse Teseo, o herói que tinha vindo combater o monstro, sugerindo-lhe que repassasse o novelo de lã que lhe permitiria voltar sobre seus passos à medida que avançasse. Por isso, Dédalo foi encarcerado por Minos e, então, fugiu com umas asas que ele mesmo fabricou para si até se refugiar na Sicília (Grimal, 1989, p. 130). Sócrates se refere a ele também no final do Ménon (97e) como criador de estátuas que precisam ser encadeadas porque, senão, não permanecem no lugar. No contexto do Ménon, compara essas estátuas de Dédalo com as opiniões verdadeiras que só têm valor se ficam quietas e então se tornam conhecimentos (epistêmai) estáveis (98a).

Eutífron diz que Sócrates parece Dédalo (11d). Sócrates aceita a comparação e se considera ainda mais terrível que aquele em sua arte na medida em que, enquanto Dédalo só fazia que não permanecessem em seu lugar suas obras, Sócrates faz o mesmo com as suas e também com as dos outros. Mais ainda, Sócrates afirma que ele é sábio, especialista (sophós, 11e), nesta arte involuntariamente, pois desejaria que suas razões ou argumentos (lógous, 11e), permanecessem quietos, sem mexerse.

Esta comparação nos lembra uma outra que Mênon faz a Sócrates no diálogo homônimo, depois que este lhe pergunta o que é a excelência ou virtude (aretê, Mênon 79e). A Mênon acontece perante Sócrates o que ele já tinha ouvido falar que aconteceria antes de conhecê-lo: "que não fazes nenhuma outra coisa a não ser cair tu mesmo em aporia e fazer com que os outros caiam em aporia" (79e- 
80a). Mênon se sente enfeitiçado, dopado e encantado inteiramente por Sócrates, submergido na mais completa aporia. Diz que Sócrates é totalmente semelhante a um pez torpedo marino que entorpece a todos quantos se aproximam dele (80a), pois ele, Mênon, está "verdadeiramente entorpecido, na alma e na boca" e não sabe mais o que responder (80a-b). Depois de ter pronunciado inúmeros discursos sobre a excelência ou virtude, frente a numerosos auditórios, agora sequer pode dizer o que ela é. E afirma que ainda bem que Sócrates não viajou fora de Atenas porque se tivesse feito tais coisas em outra pólis, como estrangeiro, teria sido julgado como feiticeiro.

Nos dois casos, o efeito parece ser semelhante. Como Dédalo ou como pez torpedo, Sócrates não deixa as coisas quietas e o faz de uma maneira que seus interlocutores perdem seu chão, já não mais conseguem fazer pé. Eis o valor de uma experiência. A conversa de Sócrates tem o efeito de um feiticeiro que faz com que os outros deixem de sentir-se cômodos e seguros no seu lugar.

No Mênon, Sócrates aceita a comparação com a condição de que o pez torpedo comece por ele mesmo e faça com que os outros fiquem entorpecidos depois dele mesmo ficar assim: "pois eu mesmo não estou em bom caminho quando levo os outros a estarem em aporia; ao contrário, como eu estou em aporia mais do que ninguém, assim levo também os outros a estar em aporia" (Mênon 80c). Sócrates deixa claro que não há qualquer problema no estado de aporia para quem busca conhecer alguma coisa e o faz dialogando com outro. O problema seria ficar numa posição de exterioridade, problematizando os outros sem problematizar-se a si próprio. Nos dois casos, Sócrates aceita as comparações à vontade, e elas parecem indicar alguma coisa substancial sobre a dimensão pedagógica de sua experiência: ensinar teria a ver com fazer que os outros saiam do lugar sob a condição de que quem supostamente ensina também saia do seu lugar.

Voltemos ao nosso diálogo. Depois do enjôo de Eutífron, a troca continua. Sócrates consegue, com muitas dificuldades, que Eutífron concorde em que o sagrado é uma parte do justo e que se trata de especificar precisamente que parte é essa (12a-12e). A conversa ganha novo impulso e Eutífron até parece avançar na direção que Sócrates quer levá-lo quando afirma que o sagrado é a parte do justo que diz respeito ao tratamento que se dá aos deuses e a outra parte do justo diz respeito ao tratamento que se dá aos homens (12e). Mas ainda falta algo pequeno, diz Sócrates, que pede esclarecimentos sobre o tipo de tratamento do qual fala Eutífron (13a). Neste detalhe, nesse algo menor que falta para que a discussão chegue a bom término, os interlocutores se perdem. Parecem cansados um do outro e o desenrolar da conversa não traz qualquer novidade. Eutífron insiste em que aprender sobre estas coisas é um trabalho e tanto (14a-b) e Sócrates acusa-o de não querer ensinar-lhe (14b) e de voltar a seus mesmos argumentos. Agrega que Eutífron é inclusive mais artista do que Dédalo na medida em que consegue que seus argumentos andem em círculos (15b-c). O tom enfadado de Sócrates parece indicar o fracasso de uma experiência: depois de tantas voltas, Eutífron vai parar no mesmo lugar do início. 
O Eutífron, então, acaba sendo um exemplo de uma dessas conversações em que o interlocutor de Sócrates não consegue dar uma resposta que lhe resulte satisfatória sobre o assunto indagado. Sócrates não consegue se satisfazer com as respostas outorgadas ao "quê" de alguma virtude ou excelência. O final do Eutífron é também exemplar em outro sentido talvez ainda mais interessante. Perante a enésima e última insistência de Sócrates em que lhe diga o que é o sagrado e o nefando, 'Eutífron' sai correndo, às pressas; escapa de Sócrates. Deste modo, repete o que outros interlocutores mostram em outros diálogos. Sócrates não mostra estar fazendo o que diz, na Apologia, com os que dialogam com ele: instruilos a que sigam uma vida filosófica. Eutífron acaba o diálogo pensando exatamente o mesmo que pensava ao início e, com todos seus movimentos dedálicos, Sócrates não consegue tirá-lo do lugar, se não é para fugir dele próprio dando movimentos circulares que lhe permitem voltar a seu mesmo ponto de partida.

Mais ainda, o próprio Sócrates não parece ter aprendido nada na parte final do diálogo. Sua última intervenção (15e-16a) é esclarecedora: Sócrates lamenta que, perante a fuga de Eutífron, fique impossibilitado de aprender o que é o sagrado e seu contrário, o que lhe permitiria: a) saber se defender da acusação de Meleto; b) não fazer novas invenções por desconhecimento e c) viver uma outra vida, melhor. Assim, ele mesmo parece voltar ao mesmo lugar do início. Será mesmo isso que faz a experiência da filosofia?

\section{Sócrates e o amor amigo}

Vamos analisar outro exercício, diferente, contrastante. É outro diálogo de juventude de Platão, o Lísis. O seu início mostra Sócrates caminhando de um bairro (Academia) para outro (Liceu), "por fora do muro" que rodeava Atenas pelo nordeste. Ele contorna a cidade, pela parte externa, não entra nela, e seus pontos de partida e de chegada marcam dois bairros cheios de ginásios e palestras. $\mathrm{O}$ filósofo vai de um para outro. A imagem é uma metáfora do movimento da filosofia e do caminho que transita o filósofo, na beira do centro da pólis. O filósofo anda entre esses bairros suburbanos; ele "corre por fora" do centro, nas margens, nos limites, entrando e saindo, num ponto fronteiriço, que não é mesmo um afora, mas também não é um adentro.

Nesse caminho, Sócrates "tropeça" com vários jovens, dentre eles, Hipotales e Ctesipo (Lísis, 203a). O primeiro convida Sócrates para conversar com ele e outros colegas, numa palestra onde eles se reúnem sempre para conversar. Antes de aceitar, Sócrates quer saber para que é convidado e quem é o enamorado de Hipotales. Sócrates apresenta a si próprio como conhecedor, por um dom divino, de quem ama e é amado, mesmo que se reconheça inútil e ruim para muitas outras coisas. Ctesipo explica a Sócrates que Hipotales está apaixonado por Lísis, outro dos interlocutores do diálogo. Lísis também é adolescente, jovem belo e excelentemente dotado, de idade em torno dos doze ou treze anos. Segundo Ctesipo, Hipotales tem cansado todo mundo ao fazer com que ouçam os milhares de poemas vulgares e sem graça que compõe o tempo todo para Lísis. 
Na primeira parte do diálogo, Sócrates mostra Hipotales o errado de sua tática de lisonjear exageradamente Lísis com toda classe de criações poéticas aduladoras e se oferece a dialogar com Lísis para lhe mostrar o tipo de coisas sobre as quais deveria falar com ele e o modo em que deveria fazê-lo (205d-206c). A "lição" de Sócrates é rápida e categórica: o erro principal de Hipotales é oferecer toda classe de elogios ao amante antes de conquistá-lo. Esse proceder pode ser ineficaz, perigoso ou narcisista: por um lado, quanto mais alguém é elogiado tanto mais se torna difícil de deixar-se conquistar; por outro lado, se a conquista fracassa, ridículo parecerá o conquistador frustrado por não ter conseguido para si o ser elogiado; no entanto, se a conquista é bem sucedida os elogios ao conquistado serão como loas a si próprio.

Assim, depois dessa rápida refutação de Hipotales que tem toda a aparência de ser apenas uma entrada no ritmo de Sócrates, o diálogo terá lugar no interior da palestra, com Sócrates interrogando Lísis e seu primo Menexeno, de sua mesma idade (207b ss.). É curioso o lugar que ocupa Sócrates no diálogo: ele assume o lugar do instrutor, sophistés, dentro da palestra, Miceo, que é mencionado uma única vez no início. Através de perguntas e respostas, Sócrates dá toda uma lição: explicitará em palavras e ações, um modo, uma tática, de tratar ao amado que é a contrária àquela utilizada por Hipotales: se este produz todo tipo de criações aduladoras do Lísis, Sócrates submete Lísis a um interrogatório que o rebaixa, o diminui, o deixa bem pequenino, exaltando seus pontos mais fracos até que este concorda em que nada sabe e nada pode (207b-210e).

Os dois primeiros interlocutores de Sócrates se mostram dóceis e flexíveis para assimilar as lições de Sócrates. Este mantém um tom firme e por momentos cruel: diz a Lísis que seus pais confiam coisas deles aos seus escravos antes de confia-las a ele; ele mesmo, livre, é dependente em dupla ordem: primeiro, é conduzido por outro, escravo da casa, o pedagogo, até a palestra; na palestra, ele é governado por outro, seu mestre, o didáskalos. Em casa, sequer lhe é permitido pôr as mãos nos telares da mãe. Na visão de Sócrates - que Lísis aceita sem objeções - sua vida é servil e não consegue fazer nada do que deseja (208e-209a). Lísis argumenta que sua situação se deve a sua pouca idade, mas Sócrates não aceita o argumento: em casos como a escrita, a leitura ou a música, nas quais Lísis já está suficientemente dotado, seus pais confiam nele apesar de sua pouca idade. Mais do que pela idade, sua situação se explica porque ainda não está preparado o suficiente, porque não sabe o necessário, porque ainda não tem sabedoria $e$ sensatez para governar-se a si próprio e aos outros (209a-210d).

Nesta argumentação socrática, o saber e a prudência são fontes de utilidade e liberdade: somos mais úteis e mais livres quanto mais sabemos e mais criteriosos somos. É interessante notar que a conversa de Sócrates com Lísis explicita esta relação em dois níveis. Por um lado, ao nível das palavras de Sócrates, que conclui com presteza e contundência nessa direção; por outro lado, na ação dramática: Sócrates, que sabe de argumentos e das coisas do amor, escraviza Lísis nesta passagem, faz dele o que quer, o leva para onde quer e tudo o que pode fazer Lísis é acompanhar mansamente e render-se a seu dono no momento. Sócrates argumenta que o saber dá liberdade, entendida como o governo de si e dos outros 
e a conversa mostra um Sócrates absolutamente dono de si e de todos os outros. Ao contrário, os que não sabem do amor, como Lísis, são escravos de outros. A verdade é que Sócrates consegue com sua arte o que Hipotales não conseguiu com sua juventude e seus poemas: seduzir e conquistar Lísis.

É particularmente interessante e curiosa a conclusão de Sócrates: o fato de que Lísis tem um mestre é uma prova de que ele não é suficientemente prudente; se o fosse não necessitaria mestre $(210 \mathrm{~d})$. A princípio poderia parecer que Sócrates afirma aqui uma visão negativa do aprender e que, por isso mesmo, contradiria o que ele tão enfaticamente afirma na Apologia e em outros diálogos. que ele mesmo consagrou-se, livremente, a aprender de todos os outros que sabem sobre aqueles assuntos que ele ignora. Mas é crucial notar que a palavra que Sócrates usa aqui para mestre, didáskalos, não designa qualquer tipo de relação de ensino $e$ aprendizagem senão especificamente aquela que caracterizamos como da ordem da instrução. É a necessidade de alguém ter um instrutor que é um signo de imaturidade. Isto todos os "Sócrates" dos diálogos o aceitariam sem objeções.

Assim, esta passagem do Lísis reforça e complementa aquela negativa de Sócrates na Apologia quando declara não ter sido mestre (didáskalos, 33a) de alguém. Sócrates não foi mestre de ninguém no sentido em que o mestre, didáskalos, para Sócrates, era apenas um instrutor, alguém que simplesmente repassava um conhecimento para o aluno que estava desprovido das condições mínimas para outro tipo de intercâmbio e que fazia isto de um modo técnico, sem problematizar as condições e os sentidos de tais saberes. Por isso, embora ele mesmo, Sócrates, na passagem que acabamos de sintetizar do Lísis, faça algo semelhante ao que qualquer mestre faria corriqueiramente, à diferença de qualquer mestre instrutor, Sócrates faz algo a mais e é precisamente nesse algo a mais que se assenta seu diferencial. O que diferencia Sócrates não está, sobretudo, no conteúdo do que ele diz ou na instrução que ele oferece; não é algo da ordem da transmissão de uma matéria, mas o impacto que esse contato pode ter sobre o seu interlocutor.

Assim, se um instrutor repassa uma série de conteúdos de gramática, de música ou de aritmética, Sócrates problematiza algumas das virtudes ou excelências que perpassam e dão sentido aos conteúdos das artes que os instrutores ensinam. Ele pretende provocar nos seus interlocutores uma mudança na relação que eles têm consigo mesmos e com seus semelhantes frente a essa virtude ou excelência. Se o instrutor está preocupado no "quê" da aprendizagem, Sócrates está mais preocupado no seu "para quê"; se o primeiro oferece instrumentos, Sócrates promove sentidos e, mais importante, uma problematização dos sentidos dominantes na pólis e uma abertura de novos sentidos.

Digamos isso com outras palavras. Em vários diálogos há - como já vimos no caso do Eutífron - um tipo especial de pergunta que interessa a Sócrates, do tipo "o que é x?", sendo "x" uma das denominadas virtudes, como a valentia (Laquês), a prudência (Cármides) ou, como no Lísis, a amizade. As perguntas nunca são respondidas satisfatoriamente. O que há, então, por trás desse jogo de perguntas que se repetem sem poder ser respondidas? O que interessa Sócrates é provocar um modo de relacionar-se com essas perguntas, uma forma de perguntar na qual a 
interrogação se inicia em um conceito externo, abstrato, e se desloca até chegar ao próprio sujeito que se faz a pergunta. Assim, o interrogar pela natureza de uma virtude leva a interrogar-se pela natureza da relação que alguém tem com a virtude, pelo próprio ser ou não ser virtuoso.

Deste modo, o sentido principal dessas conversações socráticas não é o de que o outro saiba algo que não sabia, nem sequer, como parece, que deixe de saber algo que acreditava saber, mas, fundamentalmente, que transforme sua relação com o saber. Em palavras de Pierre Hadot: "O verdadeiro problema não é, então, saber isto ou aquilo, senão ser de uma ou de outra maneira". (Hadot, 1999/1995, p. 56).

Numa conhecida passagem do Teeteto, Sócrates explicita estes sentidos de seu interrogar e reforça o papel e o lugar de quem aprender nessa sua prática educativa. Ali ele se compara com as parteiras: como elas, ele não tem nenhuma sabedoria que ensinar (150c); não é ele a fonte da instrução, não é ele um didáskalos. Talvez por isso, os que o rodeiam dão a impressão, em um primeiro momento, de serem ignorantes, mas é admirável, afirma Sócrates, como eles progridem, sem que ele jamais tenha lhes transmitido qualquer coisa. São eles mesmos, continua a afirmar Sócrates, que procuram e encontram muitas coisas belas por si próprios (150d-e). Nesta concepção, ensinar não diz respeito à transmissão de um saber de alguém que o saberia para alguém que o ignoraria, mas a provocar no outro esse desejo de aprender que os levará a procurar e encontrar o que ninguém pode procurar e encontrar por ele. Como veremos, neste sentido, o Lísis oferece um testemunho muito diferente do Eutífron.

Retomemos o Lísis. O diálogo entra num interlúdio (210e-211e) para uma nova conversa, desta vez entre Sócrates e Menexeno, que é apresentado como discípulo de Ctesipo. Este espaço preliminar à continuação do diálogo mostra aspectos interessantes para o nosso estudo. Lísis evidencia signos positivos da conversa anterior, algo assim como os primeiros efeitos de alguém que começa a estar em condições de buscar e procurar por si próprio: pede docemente a Sócrates para que este diga a Menexeno o que anteriormente tinha dito para ele; aceita o pedido de Sócrates de ele mesmo contar o conversado para Menexeno - já que acompanhou com muita atenção a conversa anterior - e, por último, se mostra ávido para que Sócrates diga alguma outra coisa a Menexeno até que seja a hora de partir.

Sócrates aceita o pedido de Lísis "já que tu me o solicitas" e pede para lhe ajudar caso Menexeno o contradiga. Sócrates pergunta a Menexeno quem é que ama a quem numa relação amorosa (quem é amigo de quem numa relação de amizade): o amante ama o amado ou o amado ama o amante (quem propõe ativamente a amizade é amigo de quem recebe essa proposta ou, ao contrário, quem recebe a amizade é amigo de quem a propõe, 212b)? Os termos gregos phílos (adjetivo, aparece também substantivado) e philía (substantivo), utilizados freqüentemente em diante no Lísis têm essa dupla significação de amigo/amante e de amor/amizade. Em As Leis, Platão diz que quando algo phílos se torna veemente o chamamos de erotikós (VIII, 837a). 
Menexeno não se dá bem em responder esta pergunta. Primeiro propõe que as duas opções são válidas, mas não consegue responder as complicações que Sócrates introduz na conversa. Uma de duas: ou a reciprocidade é uma condição da philía (amor, amizade) e então ficam fora da relação de amor, amizade, relações não correspondidas, como a philía por coisas tais como um cavalo, uma codorna, um cachorro, um vinho, a ginástica, o conhecimento, ou um bebê recém nascido, ou ainda por pessoas que simplesmente não correspondem esses sentimentos; ou então a reciprocidade não é condição da philía e caímos na contradição de que alguém ama a quem o odeia ou é amigo de quem é seu inimigo (212b-213b).

Sócrates conclui que o fracasso se explica porque não buscaram bem (213d) e, então, diz que vai dar descanso a Menexeno, para retomar a conversa com Lísis. É evidente que se trata de uma escusa para poder conversar mais com quem mais lhe interessa. A conversa com Menexeno foi curta, quase impossível de ter cansado alguém. E Sócrates não é daqueles que dão muita atenção ao cansaço de seus interlocutores. É evidente que suas razões para deixar de conversar com Menexeno e para voltar a conversar com Lísis, não têm a ver com o cansaço daquele, mas com a atração que lhe geram a curiosidade, a disposição para a filosofia (213d7) e a beleza de Lísis.

Com Lísis, Sócrates volta ao ponto em que teriam se perdido na indagação com Menexeno. Esse ponto leva ao encontro de poetas como Homero e pensadores como Empédocles e Anaxágoras, os que coincidem em afirmar que "o semelhante é amigo (ama) do semelhante" (214a-b). Sócrates restringe este pensamento moralizando-o: os semelhantes que são bons são amigos entre si, já que os que são maus jamais podem chegar a uma verdadeira amizade, na perspectiva de Sócrates. Porém este caminho também leva a um novo extravio, na medida em que os bons são auto-suficientes e, portanto, separados, não se precisam e juntos não tiram proveito um do outro (214c-215c).

Sócrates, então, puxa para numa nova fase da conversa em que volta a intervir Menexeno: recorre a Hesíodo, que afirma o contrário de Homero: só é possível a amizade entre os não semelhantes, os opostos, os contrários. Esta tese, atraente em princípio, também leva à contradição. Se os opostos se atraem, então a amizade atrairá a inimizade, o justo atrairá o injusto e o bom, o mal (215d-216b). Assim, as duas teses dos maiores poetas da Grécia, tanto a de Homero quanto a de Hesíodo, levam à contradição (216b).

Sócrates, aturdido pelo caminho andado e desandado, postula uma nova hipótese: além do bom e do mal, deve ter um terceiro gênero, as coisas nem boas, nem más. Talvez, então, a amizade seja uma relação entre coisas boas e coisas que não são boas ou más (216d-217b) ou, mais precisamente, o que não é bom ou mal será amigo do bom pela presença potencial do mal nele. Sócrates dá dois exemplos de algo que não é bom ou mal. Primeiro, o corpo, que busca a saúde pela ameaça de que a doença esteja presente nele. Segundo, o saber. Há homens ou deuses que já sabem (os "bons") e, portanto, não desejam saber. Há os homens que ignoram em sentido forte (os "maus") e, portanto, também não desejam saber. E há um terceiro 
tipo, os que não sabem, mas estão cientes de que não sabem e desejam saber. São apenas estes, que não são bons ou maus, os únicos que desejam saber (formas do verbo philosopheîn aparecem várias vezes em $218 \mathrm{a}-\mathrm{b})$.

Se o primeiro exemplo diz respeito ao corpo, o segundo diz respeito à alma, o que permite a Sócrates chegar a uma definição "completa" da amizade ou do amor no ser humano: o que não é bom ou mau nele, tende (é amigo ou amante de) ao bem pela presença ameaçante do mal (218c). Porém, logo Sócrates percebe que esta definição também tem problemas e há algo que precisa ser considerado com muito cuidado: se algo tende ao bem, se ele é amigo ou amante, o é por alguma outra coisa que faz nele um bem; assim, por exemplo, o corpo é amigo da saúde porque deseja ou quer ser amigo de outra coisa que a saúde lhe traz; de um modo geral, se é amigo de algo porque se é também amigo de alguma outra coisa que esse algo traz. Deste modo, será necessário remontar-se até o primeiro princípio, aquilo verdadeiramente amigo ou amante, em vistas ao qual todas as outras coisas são amigas ou amantes. Assim, todas as outras coisas não serão então amigas ou amantes em sentido próprio já que só são amigas ou amantes em função deste princípio (219c-d). Portanto, realmente amigo ou amante será aquilo que é amigo ou amante por si mesmo e não por outra coisa que é amiga ou amante (220b).

\section{3. $O$ valor de dois exercícios: Sócrates, o sagrado e a amizade}

Entre o Eutífron e o Lísis há tanto semelhanças quanto diferenças. Importa notar algumas das primeiras: ambos diálogos têm, desde o começo até o fim, um assunto principal, que lhe dá unidade e sentido à conversa: o que é uma virtude ou excelência (o sagrado, no Eutífron; o amor, a amizade, a afeição, philía, no Lísis). Porém, desta semelhança surge uma sutil mas significativa diferença: no primeiro, o sagrado aparece o tempo todo confrontado com seu contrário, o nefando; no Lísis, no entanto, o contrário da amizade não aparece senão esporadicamente. A diferença de ênfase é notória e se deve provavelmente ao contexto de cada diálogo. No Eutífron, é preciso conhecer a natureza do sagrado porque o ato que Eutífron está a ponto de celebrar (iniciar um processo contra seu pai) pode ser em verdade um ato contrário, nefando. No Lissis a investigação da philía adquire apenas a forma positiva de relação que merece ser cultivada pelos jovens que fazem parte da discussão. Outra semelhança é que nos dois diálogos Sócrates refuta as formas afirmativas que são colocadas para responder a pergunta de ocasião. Mas, como veremos a seguir, esta semelhança também esconde uma profunda diferença nos sujeitos, modos e impactos destas refutações. O cenário dos dois diálogos é igual nos seus inícios: a rua; porém, se Sócrates e Eutífron parecem permanecer ali durante o resto do diálogo, no Lísis a conversa se translada a uma palestra.

Algumas outras diferenças entre o Eutífron e o Lísis são também perceptíveis à primeira vista. No Eutífron há uma única conversa solitária com um interlocutor só, sem testemunhas ou observadores, e o interlocutor é alguém de idade e bem conhecido pela sua arte. No Lísis os interlocutores são quatro, todos novos e pouco conhecidos - só Ctesipo tem mais idade. Ali, a conversa tem lugar por etapas em que os interlocutores se revezam e há sempre outras pessoas assistindo às 
conversas. No primeiro diálogo, Sócrates se coloca desde o começo como alguém que não sabe e quer aprender o que o outro (Eutífron) sabe sobre o assunto em questão. Ali Sócrates ignora e quem sabe é o seu interlocutor. No Lísis a situação é inversa. Os que ignoram são os interlocutores de Sócrates e este é quem sabe. Sócrates, o mesmo que na Apologia declarava nada saber de grande valor e, a uma só vez, ser o mais sábio dos homens, segundo o Deus em Delfos, declara no Lísis que é também do deus que obteve seu saber sobre a philía. Este saber consiste em poder reconhecer quando alguém é amante e quando é amado. De éros e philía é uma das poucas coisas que Sócrates se declara sabedor também em outros Diálogos. Das coisas do amor, e de nenhuma outra, Sócrates se diz conhecedor, por exemplo, no Banquete (177d).

Esta diferente relação com o saber faz com que a postura dos dialogantes difira significativamente no decorrer das conversas. Enquanto Eutífron exige o tratamento que merece um especialista e protesta por não ser ouvido, Lísis não está preocupado em ser ouvido por Sócrates, mas em ouvi-lo. Está tão interessado no que Sócrates tem a dizer sobre a matéria que o ouve com muito cuidado e atenção. Algumas marcas testemunham este ouvir interessado: ele é apresentado como alguém que gosta de escutar (206c), que esteve muito atento na conversa (211a), e que quer continuar ouvindo outras coisas (211b). O final dos diálogos consagra esta diferente relação com Sócrates: Eutífron foge irado e não quer mais conversar com Sócrates; ao contrário, os jovens interlocutores do Lísis são levados contra sua vontade, depois de tentar convencer seus pedagogos a deixá-los conversar mais um pouquinho com ele. Se o final do Eutífron alarga as distâncias entre Sócrates e Eutífron, o final do Lísis é cheio de cumplicidade e Sócrates se declara amigo daqueles jovens que não conhecia no início da conversa.

Outras diferenças merecem mais atenção e análise. Segundo observamos, o percurso e o final do Eutífron são, filosófica e pedagogicamente, decepcionantes: Sócrates não ouve senão o que quer que os outros digam e ele e Eutífron, depois de muitas voltas, não conseguem sair do lugar. No Lísis, o percurso e o final são diferentes. Não é que Sócrates ouça com mais atenção os outros — de fato, não parece que esses outros tenham muito a dizer - mas, pelo menos, ele consegue que os outros saiam do lugar que ocupavam, a partir de sua intervenção. Talvez pelo fato de serem novos, a intervenção de Sócrates faz uma diferença nestes interlocutores: por exemplo, Hipotales percebe como deve mudar a forma de sua relação com Lísis; Menexeno já não pensará da mesma forma sobre o que faz com que um amigo (ou amante) seja amigo (ou um amante); Lísis já não pensa mais como antes de conversar com Sócrates que sua situação servil - em casa e fora dela - se deva a sua pouca idade, mas a sua falta de saber e prudência; e todos eles têm elementos para pensar por que são amigos ou amantes de seus amigos ou amantes e o que é e o que não é que faz com que sejam uma coisa ou outra.

Assim, o Eutífron e o Lísis são dois exemplos diferentes, quase opostos, de exercícios socráticos. Se no final os dois coincidem em não conseguir responder a pergunta que atravessa o diálogo, o que é o sagrado e o que é amado ou amigo, o caminho que transitam e o sentido que provocam ambos fracassos são muito diferentes. No primeiro, Sócrates não consegue nada do que se propõe com 
Eutífron. No segundo, ele consegue insuflar o que mais lhe interessa nessas almas jovens - e em particular na alma jovem, bela e boa, filosófica, de Lísis: o desejo fervoroso e inextinguível de querer saber mais para assim se elevar até perceber as condições que lhe possibilitarão chegar a uma existência livre, prudente e dona de si própria.

Contudo, chama a atenção uma forte diferença no promotor da experiência, Sócrates, que, ele próprio, mostra movimentos contrastantes: permanece no seu lugar (no Eutífron) e sai do seu lugar (no Lísis). Sócrates passa de não saber a saber (no Eutífron) e de saber a não saber (no Lísis). É interessante notar que, à luz dos efeitos logrados nos seus interlocutores e aos próprios critérios que, segundo vimos, Sócrates estabelece para apreciar uma experiência, o segundo parece ser o caminho necessário para que essa tal experiência possa ser chamada de filosófica e tenha os efeitos pedagógicos desejados. Este é o caminho de um pensamento que se deixa atravessar por outro pensamento, para encontrar um novo lugar. Interessa notar que, nos diálogos socráticos, quase não há marcas desse lugar de chegada, o que talvez seja um indício de que o mais interessante está sempre no meio, nas surpresas, nos desvios inusitados, no encontro com aquilo que não era possível antecipar no início do caminho.

Por último, é também possível que a diferença na postura de Sócrates tenha algo a ver com as temáticas de cada diálogo: o movimento que exige o amor/amizade, a quietude que clama o sagrado. Não é por acaso que uma das partes da acusação que terminou condenando Sócrates estava ligada às temáticas do Eutífron e que, ao contrário, ele fosse tão bem sucedido nas questões envolvidas no Lísis. É também evidente que o movimento ou falta de movimento de Sócrates tem muito a ver com seus interlocutores, sua idade, seu corpo, sua posição social, sua relação com o saber. Assim, os diálogos deixam ver a complexidade do que se passa entre pelo menos duas cabeças e dois corações cada vez que algo da ordem da experiência tem lugar entre eles. E sugerem, por fim, que essas cabeças e esses corações já não poderão pensar e sentir como antes de seu encontro. Pelo menos se chamamos a esse encontro de experiência do filosofar.

\section{Referências bibliográficas}

BRICKHOUSE, Thomas C., SMITH, Nicholas D. Socrates on Trial. Princeton: Princeton University Press, 1989.

DELEUZE, Gilles, GUATTARI, Félix. O que é a filosofia? São Paulo: Editora 34, $1993 / 1$.

EGGERS Lan, Conrado. "Estudio Preliminar". In: Apología de Sócrates de Platón. Buenos Aires: EUDEBA, 1984.

GRIMAL, Pierre. Diccionario de mitología griega y romana. Barcelona: Paidós, 1989. 
HADOT, Pièrre. O que é a filosofia antiga? São Paulo: Loyola, 1999/1995.

PLATÃO. Diálogos. Trad. Carlos Alberto Nunes. Belém: Universidade Federal de Pará, 1980.

SCOTT, Gary. Plato’s Socrates as Educator. New York: SUNY Press, 2000. 